\title{
Theory on The Relationship between Man and Nature in Marxism and Environment Construction of New Socialist Countryside in Hainan Province
}

\author{
Hong Suo \\ School of Economics and Management, Hainan Normal University, Haikou 571158, China
}

Keywords: Marxism, Theory of relationship between man and nature, New Socialist countryside in Hainan Province, Environment construction

\begin{abstract}
CPC National Congress has put it forward that "we must establish the concept of ecological civilization that the nature should be respected, conformed to and protected" . Harmonious development between man and nature has become an important target of socialist construction. In order to improve the economic level of rural areas, the state has strengthen the construction of new socialist countryside, and strives to achieve the harmonious development of the society and the natural environment through the construction of a new socialist countryside. Hainan, located in the south of China, is rich in resources and long in history. The country explores to construct a new socialist countryside in Hainan, so as to optimize the industrial structure of Hainan, and thus promote economic growth in the region. Marxist theory of relationship between man and nature, taking nature as the core, and the harmonious development of man and nature as the prerequisite for social development, thus correctly guides the construction of the new socialist countryside. In this paper, theory of relationship between man and nature in Marxism is to be studied, and its impact on the construction of new socialist countryside in Hainan Province is to be analyzed, so as to provide a favorable basis for the harmonious development of society.
\end{abstract}

\section{Introduction}

China is a big agricultural country. The country cannot have comprehensive development without the construction of rural environment. At present, in order to improve the ecological environment, and to increase the construction of new rural areas, theory of relationship between man and nature has to be taken as the core content, in order to promote the rapid growth of regional economy through the optimization of the ecological environment. Hainan, as a tourist area, has unique natural advantages, so the country also hopes to build a new socialist countryside in Hainan, and thus promote the comprehensive development of agriculture and tourism. Because of the clear view of nature in the theory of relationship between man and nature, which also takes protecting and optimizing the natural environment as an important principle, and the ecological civilization as the key content of the socialist construction, so it has a guiding significance for the construction of the new socialist countryside in Hainan. Therefore, in order to achieve a successful construction of socialist new rural areas, we must put Marxist theory on the relationship between man and nature as the theoretical basis of the strategy, so as to achieve the sustainable development of economy and environment, and ultimately accelerate Hainan's economic growth rate.

\section{An Overview of The Theory on The Relationship between Man and Nature in Marxism}

Marxist theory of relationship between man and nature is formulated from the point of view of man and nature, by combining the specific national conditions of the country. It affirms the correlations between man and nature, as well as the interactions, which can play a significant role in the construction of the socialist harmonious society. It is pointed that "Nature, on its own terms, is not a person's body, but an inorganic body" . Based on the above, we can make a judgment that people and the nature does not have primary and secondary relations, but each has its own unique role and value. Only by the coordination, can their greatest role be played. Based on this theory, we can 
see that if human beings want to survive, they must be kind to nature, and balance the relationship between human and nature through joint efforts, and then build a harmonious society.

\section{Relations between Theory on The Relationship between Man and Nature in Marxism and Environment Construction of New Socialist Countryside in Hainan Province}

Environment Construction of New Socialist Countryside in Hainan Province is The Application of Theory on The Relationship between Man and Nature in Marxism

The theory, starting from the national conditions, is indispensable for the environment construction in China. At the same time, the theory aims at building human and nature to a unified whole and protecting the natural environment and ecological civilization construction, so as to achieve the harmonious development of man and nature. in the process of building a new socialist countryside, Hainan government earnestly implement the important thought of the Third Plenary Session of the $18^{\text {th }}$ CPC National Congress, and taking promoting the modernization as the main task. In addition, Hainan government, in the construction of socialist new countryside, adhering to the road of ecological civilization construction, and setting this theory as a guiding ideology, and thus carries out the construction of new socialist countryside, and vigorously develops agriculture, animal husbandry, tourism and other industries, so as to enhance the economic and ecological environment in Hainan. In a word, construction of new socialist countryside in Hainan Province is the concrete manifestation of this theory. Only by ensuring the relationship between the two, will Hainan soon build a new socialist countryside, so as to improve the economic benefit of the region and optimize the natural environment.

Theory on The Relationship between Man and Nature in Marxism Plays An Important Role in Environment Construction of New Socialist Countryside in Hainan Province

With the increase of human activities, the phenomenon of tree cutting is more serious, and the ecological environment of human being has been severely damaged. At present, the state, for sustainable development of natural environment, and the harmonious relationship between human and nature, strengthens the construction of ecological civilization, especially the construction of socialist new countryside, which has been taken as the party' s central strategic plan. In order to speed up the development of rural areas, Hainan Province, spares no efforts to build a new socialist countryside, so as to enhance the speed of rural economic growth and build a harmonious environment. Of course, in the process of building a new socialist countryside in Hainan, people are the main body of the activities. If human beings use natural resources irrationally, the development of natural environment will be changed. Therefore, for the successful construction of new socialist countryside in Hainan, we must take this theory as the theoretical basis, as it has an important role in the construction of new socialist countryside. Then, human production environment can be improved, so that the construction of new socialist countryside can be on the way towards ecological civilization.

\section{Strategies of Environment Construction of New Socialist Countryside in Hainan Province}

\section{Sustainable Development Strategy}

In the process of building socialism new rural environment, Hainan Province insists on the sustainable development strategy. With the theory of the relationship between human and nature as the guiding idea, the relations between man and nature are balanced and the production of human being are controlled, so as to realize the construction of a harmonious and unified natural relationship. In the construction of the new socialist rural environment, Hainan Province needs to optimize the environment and economic structure of rural areas. In the process of production activities, the natural materials will be used to achieve the conversion of resources. In order to effectively avoid the waste of natural resources and the destruction of the environment, we must take the theory of relationship between man and nature as an important content to guide the construction of new socialist countryside in Hainan Province. For example, in the process of developing ecological wetlands in Hainan and improving rural rivers, we must adhere to the principle of sustainable development, and 
strengthen the protection of the ecological environment, in particular, to reduce the pollution of farmland and rivers. In short, the construction of the new socialist rural environment in Hainan Province must adhere to the sustainable development strategy, and thus to build a harmonious new countryside.

\section{Construction of Ecological Civilization Village}

In recent years, in order to optimize the strategy of natural environment, and to completely change the face of rural areas, the state has promoted the comprehensive development of rural areas. At the same time, to improve the rural natural environment and build ecological civilization village, since 2000, Hainan Province has set off a new upsurge in building the socialist countryside to respond to the national call ${ }^{[1]}$. The construction of the new socialist countryside plays an important role in promoting the ecological environment of the Hainan area. As the theory on the relationship between man and nature highlights the interaction and harmony between man and nature, man, nature and society can be formed into a unified whole, and then the construction of ecological civilization can be realized. Therefore, in the process of building a new socialist rural environment, Hainan Province, will take building ecological civilization village as a part of the overall strategic objectives, to protect the ecological environment in rural areas of Hainan Province, and then to achieve the objectives of the regional economy through the construction of ecological civilization village. In short, in the construction of a new socialist countryside, we must coordinate the relationship between man and nature, and set the construction of ecological civilization village as an important strategic objective, so as to realize the harmonious unification of society and environment, as well as to promote the good development of other industries in Hainan, by creating a good ecological environment.

\section{Realization of The Construction of Civil Society}

The realization of social harmony and stability is an important goal of our country, as well as improving the rural ecological environment and life to create a good living environment for the people. While constructing socialist new countryside, Hainan Province, further strengthens the farmers' spiritual civilization construction through the optimization of modern living environment, so as to realize the construction of a civilized society. The improved environment of rural areas will provide a favorable protection to the construction of rural communities that combine entertainment and education. and then the cultural life of the villagers will be enriched through the realization of rural community functions. At the same time, under the sound protection mechanism, we should strengthen the villagers' ideological and moral construction, and further enhance their ecological civilization and moral consciousness, and ultimately to build a civilized society. In the process of building a socialist new countryside in Hainan Province, the theory of the relationship between man and the nature has the guiding significance for the realization of civil society.

\section{Optimization of Resources}

Hainan Province is in the south of our country, has rich natural resources, especially the tourism resources. But in recent years, due to cuttings and natural disasters, the ecological environment has been destroyed, and the harmonious development of human and nature has been affected ${ }^{[2]}$. Therefore, in the construction of the new socialist countryside in Hainan Province, we must strengthen the construction of ecological security, setting the optimization of resources as a strategic goal, thus creating an ecological environment in Hainan Province and promoting the sustainable development of natural environment and agriculture in Hainan. So Hainan Province needs to strengthen the management of land and forest conservation. At the same time, the flood and natural disasters should be effectively prevented, and the ecological environment should be protected through the optimization of resources.

\section{The Impact of Theory of The Relationship between Man and Nature in Marxism on Environment Construction of New Socialist Countryside in Hainan Province}

\section{Promoting The Development of Industrialization}

Having the theory of the relationship between man and the nature in Marxism guide the construction of the new socialist countryside in Hainan Province, development of industrialization in 
Hainan can be promoted, and the economic growth rate in the region can be enhanced. Building a new socialist countryside, Hainan Province has not only optimized the ecological environment and protected the natural environment, but also created energy and environmental protection projects to promote the good development of animal husbandry, and built a more complete industrial chain in Hainan. For example, eco-environmental animal husbandry industry has been built, and the construction of large-scale bio-gas project has been formed. At the same time, by establishing a "pig marsh - vegetable" energy ecological mode, these resources can be used to realize the ecological farming, not only can promoting economic development, but also achieving the protection of the natural environment.

\section{Providing Direction for the Development of Tourism Industry in Hainan}

In the process of building a new socialist rural environment, Hainan Province has adhered to the theory of the relationship between man and nature, and the integrated the natural resources in Hainan, and then strengthened the development of the tourism industry, so as to provide direction for the development of the tourism industry. At present, Hainan creates a tourism project with the characteristics of Hainan through the construction of ecological civilization village and the integration of regional agriculture and tourism industry. In order to link the concept of tourism and agriculture, Hainan international tourism island should be constructed to speed up the process of the tourism industry in Hainan and to play an important role in promoting economic growth in Hainan ${ }^{[3]}$. In short, Hainan international tourism island is an important part of the new rural construction in Hainan, so it can not only optimize the ecological landscape, but also develop rural agriculture and tourism, and thus play an important part in the construction of ecologically civilized village.

\section{Improved The Ecological Function}

Marx's theory of relationship between man and nature has a profound influence on the construction of the new socialist countryside in Hainan Province. Under the guidance of this theory, the perfect ecological function of the new socialist countryside in Hainan can be realized. First, the ecologically civilized village has better environment, strengthened the service function, and education, leisure, pension service are vigorously carried out ${ }^{[4]}$. At the same time, people's living environment has been significantly improved, people here can enjoy the ease and convenience of services, and in the ecological environment, people's living and living quality can be improved significantly; Second, the process of forestry and the flower industry has been accelerated. In the new socialist countryside, people can be engaged in the ecological plantation. For example, the flowers will be more the ecological and functional, not only to achieve the ornamental function, but also to lay a good foundation of developing the tourism industry .

\section{Improving The Natural Environment}

Owning to the important significance of the theory of the relationship between man and nature, this theory has been adhered to in the construction of the new socialist countryside in Hainan, and the construction of the ecological environment in rural areas has been achieved, which makes the natural environment to be effectively improved. In the process of construction, the treatment of rural sewage is strict, and the sewage has been retreated and reused ${ }^{[5]}$. At the same time, greater efforts have been put in the construction of bio-gas engineering and environmental sanitation engineering to timely solve the problems of rural dirty. Through continuous efforts, the rural life garbage and sewage has been effective governed, and waste has been reused. As a result, the natural environment has been significantly improved. Therefore, the theory of the relationship between man and the nature has a great impact on the environment construction of new socialist countryside in Hainan Province.

\section{Conclusion}

The theory of the relationship between man and nature in Marxism, starting from the perspective of man and nature, clarifies the relationship between man and nature, and takes harmonious development between man and nature as key points. Therefore, this theory has profound influences on the environment construction of the new socialist countryside in Hainan Province. Hainan Province, for the achievement of ecological environment construction and economic growth, should 
take this theory as the theoretical basis, so as to realize the good construction of new socialist countryside.

\section{Acknowledgments}

Topic: Nature View in Marxism and Environment Construction of New Socialist Countryside in Hainan Province. Item Number: HNKY2014-45

\section{References}

[1] Zong Fang. On Farmers Environmen Right Protection from The Perspective of Ecological Civilization Construction. Ecological Economy, 2014, 30(2):49-51.

[2] Zhao Wei. Study on The Construction of The Ecological Environment in The New Socialist Countryside. Shandong Institute of Light Industry, 2011.

[3] Wang Ximing, Zhou Congmin, Wang Rui. On Construction of New Socialist Countryside in Key Ecological Function Areas from The Perspective of New Urbanization-A Case of Baisha Beautiful Countryside Construction in Hainan. Journal of Qiongzhou University, 2013,20 (6):19-27.

[4] Suo Hong. Economic Construction of New Socialist Countryside from the Perspective of Marxist Theory. People's Tribune, 2013(26):76-78.

[5] Yang Suwen, Li Defang, The Main Achievements and Basic Experience of The Construction of Civilized Ecological Village in Hainan. New Oriental, 2014(6):40-44. 